Relations industrielles

Industrial Relations

\title{
Le Congrès du Travail Canadien
}

Volume 11, numéro 3, juin 1956

URI : https://id.erudit.org/iderudit/1022628ar

DOI : https://doi.org/10.7202/1022628ar

Aller au sommaire du numéro

Éditeur(s)

Département des relations industrielles de l’Université Laval

ISSN

0034-379X (imprimé)

1703-8138 (numérique)

Découvrir la revue

Citer ce document

(1956). Le Congrès du Travail Canadien. Relations industrielles / Industrial

Relations, 11(3), 219-219. https://doi.org/10.7202/1022628ar

Tous droits réservés @ Département des relations industrielles de l’Université Laval, 1956
Ce document est protégé par la loi sur le droit d'auteur. L'utilisation des services d'Érudit (y compris la reproduction) est assujettie à sa politique d'utilisation que vous pouvez consulter en ligne.

https://apropos.erudit.org/fr/usagers/politique-dutilisation/ 
(2) Ne surveille ni ne cerne, au sens du présent article, celui qui est présent à ou près une maison d'habitation ou un lieu, ou s'en approche, à seule fin d'obtenir ou de communiquer des renseignements.

367. Est coupable d'une infraction punissable sur déclaration sommaire de culpabilité, quiconque, étant un employeur ou l'agent d'un employeur, injustement et sans autorisation légitime,

a) refuse d'employer ou congédie une personne pour la seule raison que ladite personne est membre d'un syndicat ouvrier légitime ou d'une association ou d'une association ou alliance légitime d'ouvriers ou d'employés formée pour l'avancement licite de leurs intérêts et organisée pour les protéger dans la réglementation des salaires et des conditions de travail;

b) cherche par l'intimidation, par la menace de la perte d'une situation ou d'un emploi, ou en causant la perte réelle d'une situation ou d'un emploi, ou par la menace ou l'imposition d'une peine pécuniaire, à contraindre des travailleurs ou employés de s'abstenir d'être membres d'un syndicat ouvrier ou d'une association ou alliance à laquelle ils ont légitimement droit d'appartenir; ou

c) complote, se coalise, conclut une convention ou s'entend avec un autre employeur ou son agent pour accomplir l'un des actes mentionnés à l'alinéa a) ou b).

\section{LE CONGRES DU TRAVAIL CANADIEN}

Le ministre du Travail, l'hon. Milton F. Gregg, a annoncé récemment que l'effectif des syndicats ouvriers du Canada s'établit présentement à $1,346,000$ membres. La statistique préliminaire, basée sur un relevé effectué par la Division de l'économique et de recherches du ministère du Travail, indique au ler janvier 1956 une hausse de 6 p. 100 de l'effectif syndical au regard de l'année précédente.

Durant la dernière année de leur existence distincte, le Congrès des Métiers et du Travail du Canada et le Congrès canadien du Travail ont vu s'accroître leur effectif de 6.5 et 4.6 p. 100 respectivement. En conséquence, l'effectif représenté à la réunion de fondation du Congrès du Travail canadien, laquelle a eu lieu à Toronto au cours d'avril, s'établit à environ 1,018,000 membres.

Le total estimatif des membres de chacun des congrès et des organisations indépendantes s'établit comme suit:

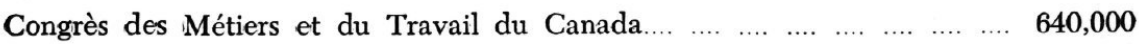

Congrès canadien du Travail.... ................................................ 378,000

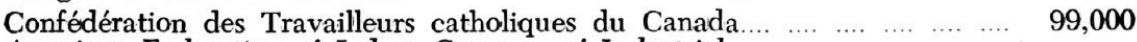

American Federation of Labor, Congress of Industrial

$\begin{array}{llllllllllllllll}\text { Organisations } & \text { seulement... } & \ldots . & \ldots & \ldots . & \ldots . & \ldots . & \ldots . & \ldots & \ldots & \ldots . & \ldots . & \ldots . & \ldots . & 1,000\end{array}$

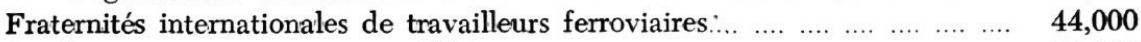

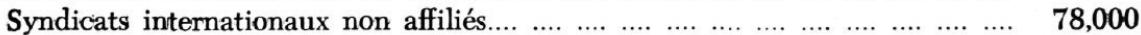

Organisations nationales, régionales et locales non affiliées................. 106,000

$\overline{1,346,000}$

* Ce texte a été fourni par le Service d'Information, Ministère du Travail, Ottawa. 